\title{
A novel mechanism of spheroidal weathering: a case study from the Monchepluton layered complex, Kola Peninsula, Russia
}

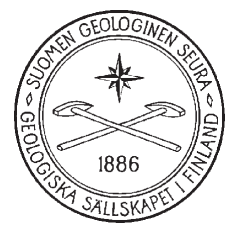

\author{
Andrei Y. Barkov ${ }^{1 *}$, ANDrey A. Nikiforov ${ }^{2}$ \\ AND ROBERT F. MARTIN ${ }^{3}$ \\ 1) Research laboratory of industrial and ore mineralogy, Cherepovets State University, \\ 5 Lunacharsky Avenue, Cherepovets 162600, Russia \\ 2) Geological Department, Voronezh State University, 1 University Square, \\ Voronezh 394006, Russia \\ 3) Department of Earth and Planetary Sciences, McGill University, \\ 3450 University Street, Montreal, Quebec H3A OE8, Canada
}

\begin{abstract}
We describe an unusual pattern of spheroidally weathered surface developed in a mineralized harzburgite of Mount Kumuzhya, Monchepluton layered complex of Early Proterozoic age, Kola Peninsula, Russia. This rock is composed of a matrix and spheroids, which differ in their paragenesis and textures. The relief spheroids consist principally of large oikocrysts (up to 3-4 cm) of orthopyroxene $\left(E n_{86}\right)$, enclosing aggregates of finegrained chromian spinel (chromite-magnesiochromite). The matrix is mostly composed of olivine $\left(\mathrm{Fo}_{90.5}\right)$, surrounded by patches of chromite. We infer that this pattern represents a new variety of spheroidal weathering of rock surface, which is not related to "normal" spheroidal weathering. Presumably, it has resulted mainly from the primary magmatic characteristics, whereas other factors, such as differential rates of weathering of olivine and orthopyroxene, were of secondary importance.
\end{abstract}

Keywords (GeoRef Thesaurus, AGI): weathering, sphericity, harzburgite, layered intrusions, mafic composition, ultramafic composition, Fennoscandian Shield, Proterozoic, Mount Kumuzhya, Kola Peninsula, Russian Federation

*Corresponding author (e-mail: barkov@chsu.ru)

Editorial handling: Pertti Sarala (pertti.sarala@gtk.fi) 


\section{Introduction}

Chemical weathering has exerted a considerable control over levels and cycles of $\mathrm{CO}_{2}$ in the atmosphere during the geological history (Berner, 1992). Also, it has had a great impact on the rate of denudation and the formation of relief, and various placer deposits. Spheroidal weathering is quite a common result of chemical weathering; it involves corestones (i.e., spheroids of relict bedrock) of various compositions and sizes, which are surrounded by concentric shells, i.e., rindlets, arranged in zones. Though mechanisms and agents of chemical and spheroidal weathering are still discussed, these processes are fairly well characterized from various geological settings (e.g., Claridge \& Campbell, 1984; Pokrovsky et al., 2005; SoubrandColin et al., 2005; Caillaud et al., 2006; Velbel, 2009).

During a field trip in the year 2014, we investigated the six mounts, namely Nittis, Kumuzhya, Travyanaya, Sopcha, Nyud, and Poaz, which compose the Monchepluton mafic-ultramafic layered complex, Kola Peninsula (Fig. 1). It is one of largest layered complexes of Early Proterozoic age $(2.5 \mathrm{Ga})$; it hosts various deposits of base-metal sulfides, chromian spinel, and platinum-group minerals (e.g., Dedeev et al., 2002; Sharkov \& Chistyakov, 2012; Chashchin \& Mitrofanov, 2014, and references therein).

Though our primary interests lie in studies of mineralogy of magmatic rocks and ore zones, we have also examined surficial patterns of weathering in the exposed bedrock. We describe here an unusual outcrop spotted on a slope of Mount Kumuzhya (Fig. 1). It shows an unusual texture of the weathered surface that contrasts with all of our observations. A spheroidally weathered surface has developed in harzburgite (Fig. 2a). However, the results reported in our communication indicate that this type of weathering is, in fact, not related with a mechanism of "normal" spheroidal weathering sensu stricto. Rather, it could be the result of another mechanism involving, as major factors, primary magmatic

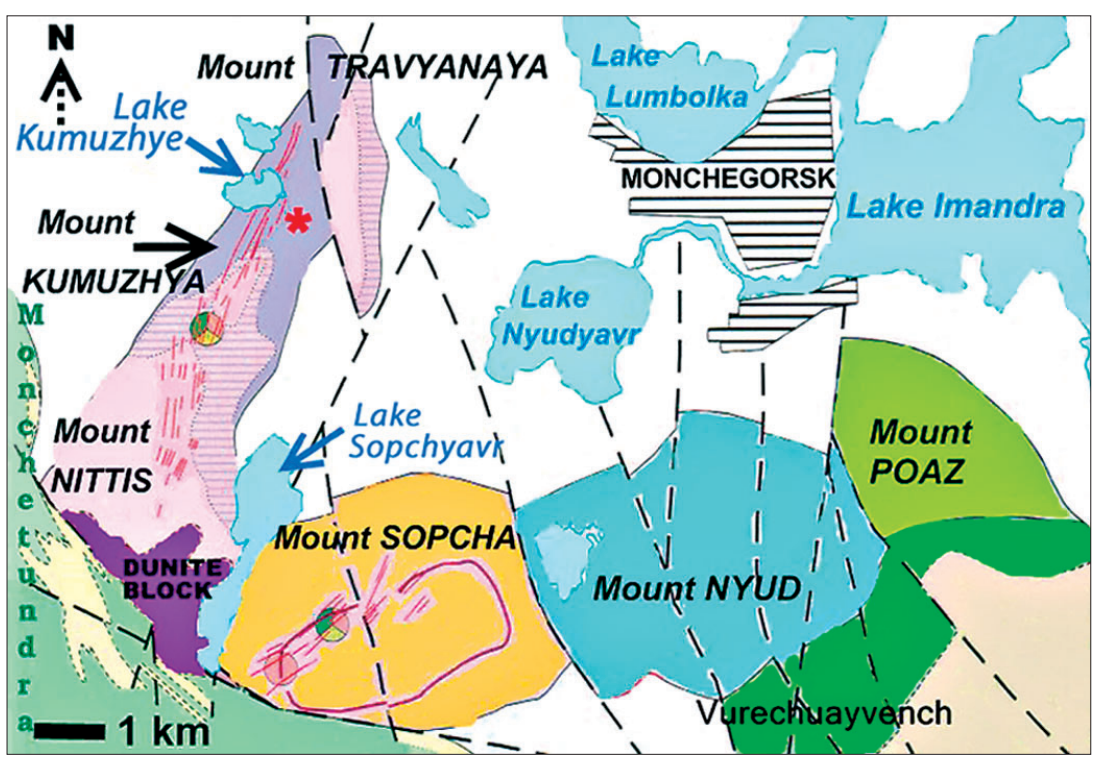

Fig. 1. A schematic geological map of the Monchepluton complex, adapted from Chashchin \& Mitrofanov (2014), with the location of the spheroidally weathered rock shown by a red asterisk. The purplish area: ultramafic rocks, principally dunite ("Dunite block"); pink area: olivine-bearing orthopyroxenite; hatched pink area: interlayering of the olivine-bearing orthopyroxenite with harzburgite; lilac area: principally harzburgite in the mounts Nittis-Kumuzhya-Travyanaya suite. In addition, yellow area: orthopyroxenite; blue area: norite; and green area: mostly gabbronorite in the mounts SopchaNyud-Poaz suite. The red lines show sulfide veins and zones of $\mathrm{Cu}-\mathrm{Ni}-\mathrm{PGE}$ mineralization. The three-colored circle refers to a $\mathrm{Cu}-\mathrm{Ni}$-PGE deposit; the pink circle indicates a low-sulfide type of deposit. The scale bar equals $1 \mathrm{~km}$. 

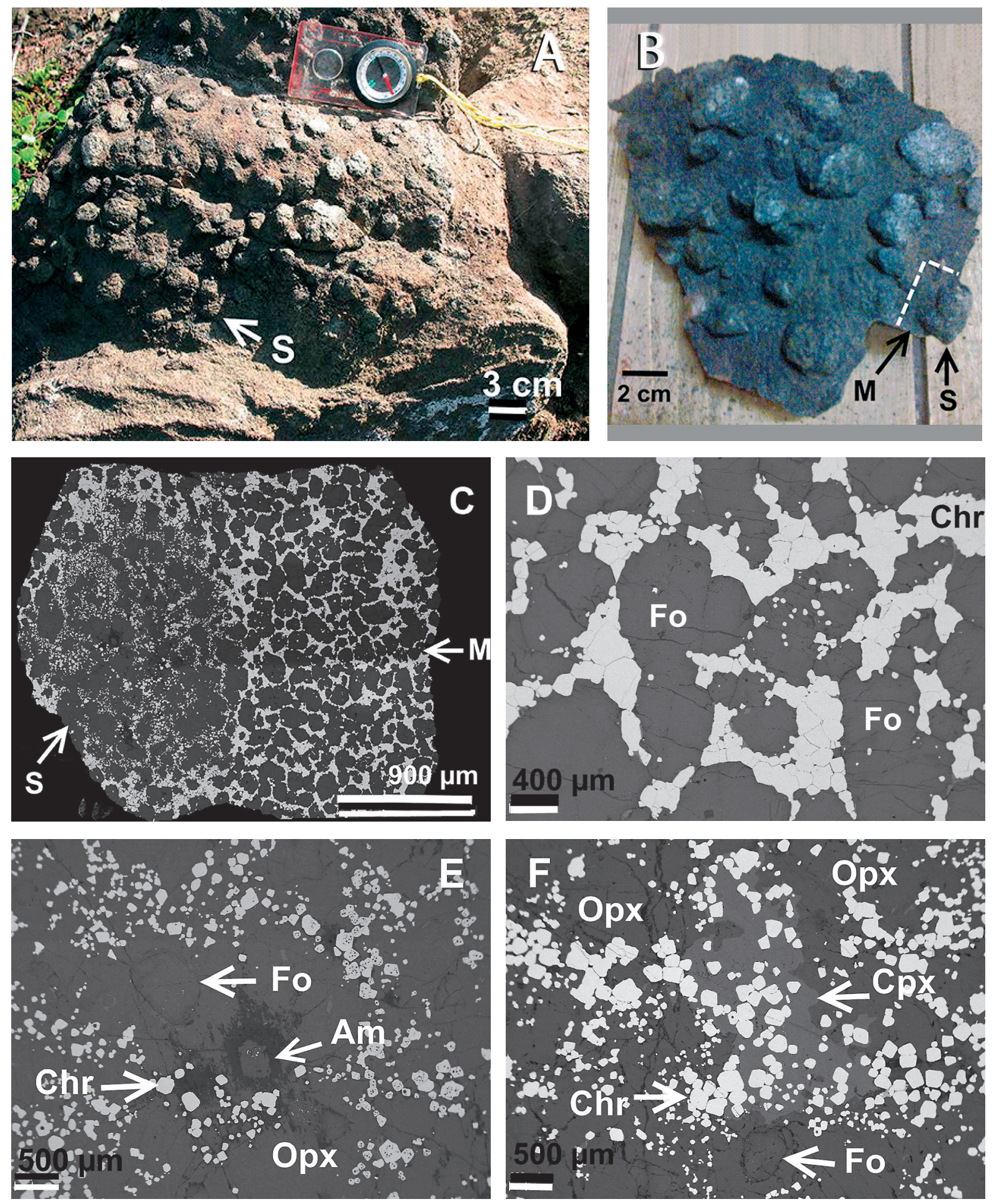

Fig. $2(\mathrm{a}-\mathrm{c})$. The outcrop and texture of spheroid-type weathered rock at Mount Kumuzhya. A: The spheroids (S) are exposed oikocrysts of orthopyroxene. $2 \mathrm{~b}$ : A specimen of the weathered rock, containing the spheroids (S) and matrix (M). The dashed white line shows the location of a polished section (also shown in Fig. 2c). Figure 2d: the observed association olivine (Fo) - chromite (Chr) in the matrix. 2e: an oikocryst of orthopyroxene (Opx) with inclusions of olivine (Fo) and chromian spinel (Chr). Am: a deuteric amphibole (tremolite). 2f: grains of clinopyroxene (Cpx), olivine (Fo), and chromite-magnesiochromite (Chr) hosted by the oikocrystic orthopyroxene (Opx) in the spheroid. 
characteristics. Our observations thus imply that, in certain cases, similar patterns of weathering may be confused with those of normal spheroidal weathering.

\section{Results and Discussion}

\subsection{Matrix, spheroids and inferred sequence of crystallization}

The spheroidally weathered rock is close to a harzburgite (up to 45-50\% orthopyroxene, $30 \%$ olivine, $20 \%$ chromian spinel, and $\leq 5$ vol. \% clinopyroxene). It is dense, unbroken and fresh, so that the weathering front appears to be surfacelimited. The mineral grains exposed at the weathered crust surface, which is black in color, show a strong internal integration with each other. Thus, it appears unlikely that such relief could have formed by a physical selective disintegration of the olivine matrix.

This rock is composed of a matrix (M) and the spheroids (S) (Figs. 2a, b), which differ in paragenesis and textures of the principal rock-forming minerals. The spheroids consist of large oikocrysts of a highly magnesian orthopyroxene, $\mathrm{En}_{86}$, up to 3-4 cm across (Fig. 2c, anal. 3, Table 1), which enclose aggregates of fine-grained chromian spinel (chromite-magnesiochromite series: anal. 9, 10, Table 1), along with separate inclusions of olivine $\left(\mathrm{Fo}_{89}\right)$ and augite (Figs. 2e, f, anal. 1, 4, Table 1). Also present, as accessory grains $(\leq 50 \mu \mathrm{m})$, are occurrences of micrograins of $\mathrm{Ni}$-rich sulfides, platinum-group minerals (laurite and skaergaardite?), and fluorapatite with inclusions of a REE-rich phase [probably monazite-(Ce)?].

The matrix (Figs. 2c, d) is principally composed of olivine grains, $\mathrm{Fo}_{90.5}$ (anal. 2, Table 1), surrounded by patches of chromite-magnesiochromite; this texture (Fig. 2d) implies that olivine crystallized before the chromian spinel. As noted, the rock is, in fact, fresh, and only contains minor amounts of deuterically formed calcic amphibole (tremolite) and talc (anal. 5, 6, Table 1), which replace the orthopyroxene (Fig. 2e).

The observed textures and compositions point to the following order of crystallization: (1) crystals
$\mathrm{Ol}(M$ : matrix $) \rightarrow(2)$ grains of $\mathrm{Chr}$, interstitial to $\mathrm{Ol}(M)$; subhedral grains of Chr hosted by Opx $(S$ : spheroid) $\rightarrow(3)$ oikocrysts of Opx $(S)$ crystallized from a more evolved (fractionated) melt; intercumulus $\mathrm{Cpx} \rightarrow(4)$ zoned $\mathrm{Chr}(M)$; and fluorapatite $(S)$ formed from droplets of trapped melts $\rightarrow$ (5) micrograins of base-metal sulfides deposited at boundaries of Chr grains $(S)$; inclusions of albite (in $\mathrm{Chr}$ ) formed from trapped microdroplets of a highly evolved melt or from microbubbles of a residual melt enriched in $\mathrm{Na}$ and $\mathrm{Si}$, which are incompatible with Chr.

\subsection{Factors of spheroidal weathering at Monchepluton}

It is known that the formation of normal patterns of spheroidal weathering sensu stricto involves the following sequence of events: rectilinear systems of microfractures $\rightarrow$ rectangular blocks $\rightarrow$ rounding of their edges and angularities (Chapman \& Greenfield, 1949; Ollier, 1971; Chatterjee \& Raymahashay, 1998; Fletcher et al., 2006; Buss et al., 2008). Indeed, no rindlets or pore spaces within a zone of rindlets, or a specific system of microfractures, are observed in our case, nor is there anything that could be ascribed to the known mechanism of normal spheroidal weathering. Thus, we suppose that the presently observed pattern formed through a different mechanism.

Several factors with a potential significance could be considered to account for the appearance of an unusual pattern of spheroidal-type weathering (Figs. 2a, b) in the mineralized harzburgite at Mount Kumuzhya. (1) The first, clearly an important one, is evident from the observed presence of large oikocrysts of orthopyroxene; they are a component of a magmatic texture (Fig. 2c). The ball-shaped morphology of the weathered surface is thus a reflection of magmatic stage of crystallization of these oikocrysts. In addition, the ball-like shape of the oikocrysts could well represent a likely cause of their higher stability to weathering, leading to a higher resistance to all of mechanical and chemical influences in the superficial environment.

(2) The second factor pertains to differences in 
Table 1. Compositions of rock-forming minerals from a mineralized harzburgite with patterns of spheroid-type weathering, Monchepluton complex, Kola Peninsula, Russia

\begin{tabular}{|c|c|c|c|c|c|c|c|c|c|c|}
\hline \multirow[t]{3}{*}{ No. } & 1 & 2 & 3 & 4 & 5 & 6 & 7 & 8 & 9 & 10 \\
\hline & s & $M$ & $s$ & $\mathbf{S}$ & $S$ & $\mathbf{S}$ & M & $\mathbf{M}$ & $\mathbf{S}$ & $\mathbf{S}$ \\
\hline & Fo & Fo & Opx & Cpx & Am & Tlc & Chr & Chr & Chr & Chr \\
\hline \multicolumn{11}{|l|}{ Weight \% } \\
\hline $\mathrm{SiO}_{2}$ & 40.08 & 40.34 & 55.93 & 52.87 & 58.36 & 62.13 & n.d. & 0.25 & 0.19 & 0.21 \\
\hline $\mathrm{TiO}_{2}$ & n.d. & n.d. & 0.06 & 0.22 & n.d. & n.d. & 0.39 & 0.36 & 0.38 & 1.44 \\
\hline $\mathrm{Al}_{2} \mathrm{O}_{3}$ & n.d. & n.d. & 1.62 & 2.42 & 0.61 & 0.19 & 15.77 & 15.91 & 18.24 & 18.74 \\
\hline $\mathrm{Cr}_{2} \mathrm{O}_{3}$ & n.d. & n.d. & 0.69 & 1.37 & 0.21 & 0.06 & 49.31 & 49.22 & 46.45 & 47.12 \\
\hline $\mathrm{V}_{2} \mathrm{O}_{3}$ & n.d. & n.d. & n.d. & n.d. & n.d. & n.d. & 0.17 & 0.13 & 0.17 & 0.13 \\
\hline $\mathrm{FeO}$ (total) & 10.15 & 8.89 & 7.32 & 3.40 & 0.86 & 0.71 & 24.37 & 24.23 & 24.56 & 22.77 \\
\hline $\mathrm{FeO}$ (calc) & - & - & - & - & - & - & 19.83 & 20.14 & 20.96 & 21.89 \\
\hline $\mathrm{Fe}_{2} \mathrm{O}_{3}$ (calc) & - & - & - & - & - & - & 5.05 & 4.55 & 4.00 & 0.98 \\
\hline $\mathrm{MnO}$ & 0.15 & 0.14 & 0.20 & 0.11 & n.d. & n.d. & 0.28 & 0.31 & 0.30 & 0.29 \\
\hline $\mathrm{MgO}$ & 49.53 & 49.87 & 32.01 & 17.36 & 23.94 & 31.28 & 9.74 & 9.75 & 9.17 & 9.43 \\
\hline $\mathrm{CaO}$ & n.d. & n.d. & 1.54 & 21.11 & 12.92 & 0.09 & n.d. & n.d. & 0.17 & 0.06 \\
\hline $\mathrm{NiO}$ & 0.36 & 0.35 & n.d. & n.d. & 0.05 & 0.14 & n.d. & n.d. & n.d. & n.d. \\
\hline $\mathrm{Na}_{2} \mathrm{O}$ & n.d. & n.d. & n.a. & n.a. & n.d. & n.d. & n.a. & n.a. & n.a. & n.a. \\
\hline $\mathrm{K}_{2} \mathrm{O}$ & n.d. & n.d. & n.a. & n.a. & n.d. & n.d. & n.a. & n.a. & n.a. & n.a. \\
\hline Total & 100.3 & 99.6 & 99.4 & 98.9 & 97.0 & 94.6 & 100.5 & 100.6 & 100.0 & 100.3 \\
\hline \multicolumn{11}{|l|}{ apfu } \\
\hline 0 & 4 & 4 & 6 & 6 & 23 & 11 & 32 & 32 & 32 & 32 \\
\hline $\mathrm{Si}$ & 0.98 & 0.99 & 1.96 & 1.95 & 7.98 & 3.97 & & 0.06 & 0.05 & 0.05 \\
\hline Al & - & - & & 0.11 & 0.10 & 0.01 & 4.79 & 4.82 & 5.52 & 5.63 \\
\hline $\mathrm{Cr}$ & - & - & 0.02 & 0.04 & 0.02 & - & 10.05 & 10.01 & 9.43 & 9.50 \\
\hline v & - & - & - & - & - & - & 0.04 & 0.03 & 0.04 & 0.03 \\
\hline $\mathrm{Ti}$ & - & & 0.002 & 0.006 & - & - & 0.08 & 0.07 & 0.07 & 0.28 \\
\hline $\mathrm{Fe}^{2+}$ & 0.21 & 0.18 & 0.22 & 0.11 & 0.10 & 0.04 & 4.27 & 4.33 & 4.50 & 4.67 \\
\hline $\mathrm{Fe}^{3+}$ & - & - & - & - & - & - & 0.98 & 0.88 & 0.77 & 0.19 \\
\hline $\mathrm{Mn}$ & 0.003 & 0.003 & 0.006 & 0.003 & - & - & 0.06 & 0.07 & 0.07 & 0.06 \\
\hline $\mathrm{Mg}$ & 1.81 & 1.83 & 1.67 & 0.96 & 4.88 & 2.98 & 3.74 & 3.74 & 3.51 & 3.58 \\
\hline $\mathrm{Ni}$ & 0.007 & 0.007 & - & - & - & 0.007 & - & - & - & - \\
\hline $\mathrm{Ca}$ & - & & 0.06 & 0.84 & 1.89 & 0.01 & - & - & 0.05 & 0.02 \\
\hline Fo & 89.2 & 90.5 & - & - & - & - & - & - & - & - \\
\hline $\mathrm{Fa}$ & 10.3 & 9.1 & - & - & - & - & - & - & - & - \\
\hline Wo & - & - & 3.0 & 44.1 & - & - & - & - & - & - \\
\hline En & - & - & 86.0 & 50.4 & - & - & - & - & - & - \\
\hline Fs & - & - & 11.0 & 5.5 & - & - & - & - & - & - \\
\hline $\mathrm{Fe} /(\mathrm{Fe}+\mathrm{Mg})$ & - & - & - & - & - & - & 0.58 & 0.58 & 0.60 & 0.58 \\
\hline $\mathrm{Cr} /(\mathrm{Cr}+\mathrm{Al})$ & - & - & - & - & - & - & 0.68 & 0.67 & 0.63 & 0.63 \\
\hline
\end{tabular}

Note. "M" and "S" pertain to analysed grains from the matrix (M) and spheroid (S). Fo is forsterite; Opx is orthopyroxene (enstatite); Cpx is clinopyroxene (augite); Am is amphibole (tremolite); Tlc is talc; and Chr is chromite. Numbers 1 to 10 pertain to representative results of WDS electron-microprobe analyses done with a Cameca MS-46 electron microprobe, at $20 \mathrm{kV}$ and $30 \mathrm{nA}$, using the following set of standards: forsterite (for $\mathrm{Mg}$ ), hematite (Fe), pyrope (Al), wollastonite (Ca and Si), lorenzenite (Ti), synthetic $\mathrm{MnCo}_{3}(\mathrm{Mn})$, chromite (Cr), and pure $\mathrm{Ni}(\mathrm{Ni})$. Fe (total) is all Fe expressed as FeO (wt.\%). n.d.: not detected; n.a.: not analyzed. Values of ferrous and ferric iron (calc) were estimated on the basis of charge balance and stoichiometry. 
rates of weathering of olivine and orthopyroxene. Indeed, it is known that Bowen's reaction series is consistent with an order of increasing stability of minerals at the Earth's surface; quartz is most stable, and olivine is least stable. It is also well known that enstatite has a greater resistance than forsterite to a chemical weathering; the susceptibility series is: $\mathrm{Ol}$ $\rightarrow \mathrm{Pl} \rightarrow \operatorname{Prx} \rightarrow$ opaque minerals (Eggleton et al., 1987). In addition, reactions of dissolution appear to differ for forsterite $\left[\mathrm{Mg}_{2} \mathrm{SiO}_{4}+4 \mathrm{H}^{+} \rightarrow 2 \mathrm{Mg}^{2+}+\right.$ $\left.\mathrm{H}_{4} \mathrm{SiO}_{4}{ }^{0}\right]$ and enstatite $\left[\mathrm{MgSiO}_{3}+2 \mathrm{H}^{+}+\mathrm{H}_{2} \mathrm{O} \rightarrow\right.$ $\left.\mathrm{Mg}^{2+}+\mathrm{H}_{4} \mathrm{SiO}_{4}{ }^{0}\right]$ (Schott \& Berner, 1985). In the climatic zone close to the sub-Arctic, "free" water is relatively rare during the long and cold autumnwinter season. If so, dissolution of the forsterite component could possibly proceed more efficiently than the dissolution of enstatite, thus promoting formation of the relief surface. (3) Also, combination of chemical weathering with a mechanical one could be expected. The studied outcrop is situated on a slope, consistent with seasonal descents of snow and glacier, resulting in mechanical influences and the episodic removal of products of weathering and fragments of disintegrated grains, mostly olivine. There is no evidence for a polished surface left by a glacial erosion in the present outcrop. However, the glacially plucked and scarred outcrops are, in general, common landforms in the Monchepluton area (Figs. 3a, b).

\subsection{Concluding comments}

(1) We infer that the ball-shaped morphology of the weathered surface at Mount Kumuzh'ya is mainly a reflection of the presence of large oikocrysts of orthopyroxene, which crystallized during a magmatic stage.

(2) The spheroidally textured rock is notably fresh, making our interpretation easier. In other cases, serious difficulties could arise if a related rock, also with oikocrysts of pyroxene, were fractured and altered by deuteric processes or during a regional metamorphism. Therefore, some of the spheroidal patterns described in the literature, and developed in weathered mafic-ultramafic rocks, could have formed by a mechanism similar to that we have proposed. A re-examination would be in order in such cases.

\section{Acknowledgements}

We are grateful to Drs. Adrian Hall, Ravi Anand, P. Sarala, Associate Editor, and J. Heinonen, Editorin-Chief, for their constructive reviews and comments. A.Y.B. thanks D.V. Afanasyev, rector of Cherepovets State University (ChSU), for his support of projects in the Earth sciences, as well as Ya.A. Pakhomovsky and Ye.E. Savchenko (Kola Science Centre, Apatity, Russia) for the electron-

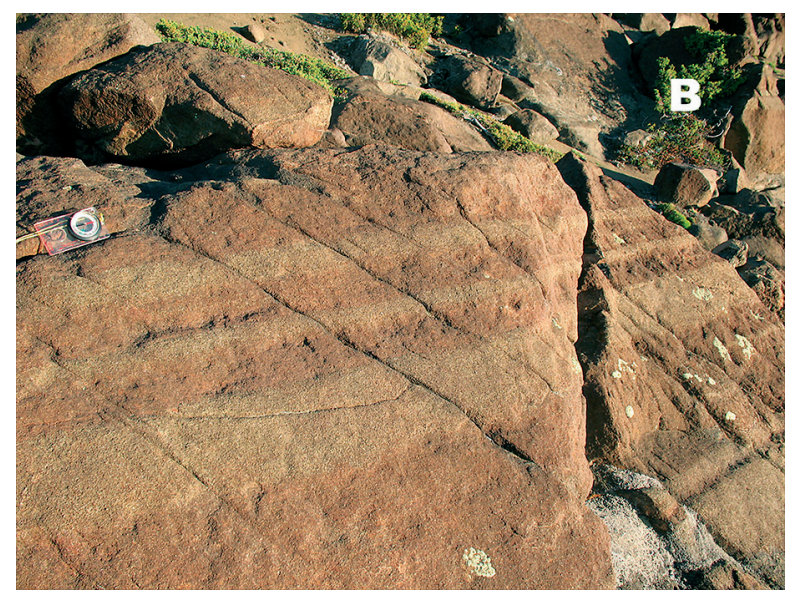

Fig. 3 (a, b). Glacially plucked and scarred outcrops and moraine, which are observed in areas of the Monchepluton complex. Note the presence of well-recognized rhythmic layering, related to modal variations observed in mafic minerals (Fig. 3b). 
probe data. We also thank Sergei Kramzaev, a staff member at the ChSU, for his assistance during the field investigation of the Monchepluton complex.

\section{References}

Berner, R.A., 1992. Weathering, plants and the long term carbon cycle. Geochimica et Cosmochimica Acta 56, 3225-3231. http://dx.doi.org/10.1016/0016-7037(92) 90300-8

Buss, H.L., Sak, P.B., Webb, S.M. \& Brantley, S.L., 2008. Weathering of the Rio Blanco quartz diorite, Luquillo mountains, Puerto Rico: coupling oxidation, dissolution, and fracturing. Geochimica et Cosmochimica Acta 72, 4488-4507. http://dx.doi.org/10.1016/j.gca.2008.06.020

Caillaud, J., Proust, D. \& Righi, D., 2006. Weathering sequences of rock-forming minerals in a serpentinite: influence of microsystems on clay mineralogy. Clays and Clay Minerals 54, 87-100. http://dx.doi.org/10.1346/ ccmn.2006.0540111

Chapman, R.W. \& Greenfield, M.A., 1949. Spheroidal weathering of igneous rocks. American Journal of Science 247, 407-429. http://dx.doi.org/10.2475/ajs.247.6.407

Chashchin, V.V. \& Mitrofanov, F.P., 2014. The Paleoproterozoic Imandra-Varzuga rifting structure (Kola Peninsula): intrusive magmatism and minerageny. Geodynamics \& Tectonophysics 5(1), 231-256 (in Russian). http:// dx.doi.org/10.5800/gt-2014-5-1-0126

Chatterjee, A. \& Raymahashay, B.C., 1998. Spheroidal weathering of Deccan Basalt: a three-mineral model. Quarterly Journal of Engineering Geology \& Hydrogeology 31, 175-179. http://dx.doi.org/10.1144/ gsl.qjeg.1998.031.p3.02

Claridge, G.G.C. \& Campbell, I.B., 1984. Mineral transformation during the weathering of dolerite under cold arid conditions in Antarctica. New Zealand Journal of Geology and Geophysics 27, 537-545. http://dx.doi.org/ 10.1080/00288306.1984.10422271

Dedeev, A.V., Khashkovskaya, T.N. \& Galkin, A.S., 2002. PGE Mineralization of the Monchegorsk layered mafic- ultramafic intrusion of the Kola Peninsula. In: Cabri, LJ (ed) The Geology, Geochemistry, Mineralogy and Mineral Beneficiation of Platinum-Group Elements, Canadian Institute of Mining, Metallurgy and Petroleum, Spec. Vol. 54, 569-577.

Eggleton, R.A., Foudoulis, C. \& Farkevisser, D., 1987. Weathering of basalt: changes in rock chemistry and mineralogy. Clays and Clay Minerals 35, 161-169. http:/ /dx.doi.org/10.1346/ccmn.1987.0350301

Fletcher, R.C., Buss, H.L. \& Brantley, S.L., 2006. A spheroidal weathering model coupling porewater chemistry to soil thicknesses during steady-state denudation. Earth and Planetary Science Letters 244, 444-457. http://dx.doi.org/ 10.1016/j.epsl.2006.01.055

Ollier, C.D., 1971. Causes of spheroidal weathering. EarthScience Reviews 1, 127-141. http://dx.doi.org/10.1016/ 0012-8252(71)90005-5

Pokrovsky, O.S., Schott, J., Kudryavtsev, D.I. \& Dupré, B., 2005. Basalt weathering in central Siberia under permafrost conditions. Geochimica et Cosmochimica Acta 69, 56595680. http://dx.doi.org/10.1016/j.gca.2005.07.018

Schott, J. \& Berner, R.A., 1985. Dissolution mechanisms of pyroxenes and olivines during weathering. In: Drever, J.I. (ed.) The Chemistry of Weathering. NATO ASI Series C, Mathematical and Physical Sciences, Reidel, Dordrecht, vol. 149, 35-53. http://dx.doi.org/10.1007/978-94-0095333-8_3

Sharkov, E.V. \& Chistyakov, A.V., 2012. The Early Paleoproterozoic Monchegorsk layered mafite-ultramafite massif in the Kola Peninsula: geology, petrology and ore potential. Petrology 7, 603-639 (in Russian). http:/ dx.doi.org/10.1134/s0869591112070041

Soubrand-Colin, M., Bril, H., Neel, C., Courtin-Nomade, A. \& Martin, F., 2005. Weathering of basaltic rocks from the French Massif Central: origin and fate of Ni, Cr, $\mathrm{Zn}$ and $\mathrm{Cu}$. Canadian Mineralogist 43, 1077-1092. http:// dx.doi.org/10.2113/gscanmin.43.3.1077

Velbel, M.A., 2009. Dissolution of olivine during natural weathering. Geochimica et Cosmochimica Acta 73: 60986113. http://dx.doi.org/10.1016/j.gca.2009.07.024 